\title{
Reduced Chemical Kinetic Model for Titan Entries
}

\author{
Romain Savajano, ${ }^{1}$ Raffaello Sobbia, ${ }^{1}$ Michele Gaffuri, ${ }^{1,2}$ and Pénélope Leyland ${ }^{1}$ \\ ${ }^{1}$ Ecole Polytechnique Fédérale de Lausanne, Interdisciplinary Aerodynamics Group, Station 9, 1015 Lausanne, Switzerland \\ ${ }^{2}$ Deutsches Zentrum für Luft- und Raumfahrt (DLR), Lilienthalplatz 7, 38108 Braunschweig, Germany \\ Correspondence should be addressed to Romain Savajano, romain.savajano@epfl.ch \\ and Pénélope Leyland, penelope.leyland@epfl.ch
}

Received 4 May 2011; Accepted 9 August 2011

Academic Editor: Jerzy Bałdyga

Copyright (C) 2011 Romain Savajano et al. This is an open access article distributed under the Creative Commons Attribution License, which permits unrestricted use, distribution, and reproduction in any medium, provided the original work is properly cited.

A reduced chemical kinetic model for Titan's atmosphere has been developed. This new model with 18 species and 28 reactions includes the mainfeatures of a more complete scheme, respecting the radiative fluxes. It has been verified against three key elements: a sensitivity analysis, the equilibrium chemical composition using shock tube simulations in CHEMKIN, and the results of computational fluid dynamics (CFDs) simulations.

\section{Introduction}

The Saturn largest moon Titan, with its thick atmosphere rich in organic compounds and nitrogen, provides similar aspects to Earth. As a consequence, numerous scientists are interested in exploring it and are hoping for hints on how life began on Earth. Thus, it is likely that new missions will follow Cassini-Huygens and try to bring more information on this orange moon. The accurate prediction of the heat fluxes during the entry of the sounding probes is crucial to the integrity of the probe and to the quality of the protection of the scientific instruments.

To investigate further the limits of these fluxes, obligatory for efficient thermal protection system design and sizing, CFDs tools are constantly developed and improved. One of the critical parameters for CFDs codes is the chemical kinetic model, as it describes the reactions schemes. However, the complexity of complete modelling is incompatible with design tools, which require fast response time simulation, and it is not necessary for such atmospheres, where the dominant species dictate the physics.

The kinetic model depends primarily on the composition of the atmosphere. Despite the recent success of the CassiniHuygens mission, uncertainties remain regarding the composition of Titan's atmosphere. The main components are $\mathrm{N}_{2}, \mathrm{CH}_{4}$, and Ar. One of the first kinetic models commonly used was proposed by Nelson et al. [1] in 1991. However, this first model does not take into account the formation of $\mathrm{CN}$ via $\mathrm{HCN}$ (as this species is not included). Also, as shown in many papers $[2,3], \mathrm{CN}$ is a strong radiator and the radiative heat flux is predominant during Titan atmospheric entries. Moreover, the reaction rates used were not up to date. Consequently, a new chemical kinetic model was proposed by Gökçen [4], it is composed of 21 species $\left(\mathrm{N}_{2}, \mathrm{CH}_{4}, \mathrm{CH}_{3}, \mathrm{CH}_{2}, \mathrm{CH}, \mathrm{C}_{2}, \mathrm{H}_{2}, \mathrm{CN}, \mathrm{NH}, \mathrm{HCN}, \mathrm{N}, \mathrm{C}\right.$, $\mathrm{H}, \mathrm{Ar}, \mathrm{N}_{2}^{+}, \mathrm{CN}^{+}, \mathrm{N}^{+}, \mathrm{C}^{+}, \mathrm{H}^{+}, \mathrm{Ar}^{+}$, and $\mathrm{e}^{-}$) and 35 reactions (rates for these reactions are given in Appendix A). Despite this new reduced model, CFDs simulations are still time and memory consuming (several hours depending on the mesh and the physics implemented). As a consequence, each species or reaction removed from Gökçen's model is a gain of time. More recently, Leyland et al. [5] proposed a reduced model; however, discrepancies were encountered for ion molar fractions. A further reduced mechanism including 18 species and 28 reactions is detailed in this paper. It has been justified by a sensitivity analysis and verified against Gökçen's model using CHEMKIN (user interface software to run reactor models) and MB_CNS (a 2D Navier-Stokes time explicit solver) from University of Queensland, Hypersonics Centre, Australia.

\section{Details of the Reduced Model}

The new model proposed contains only 18 species $\left(\mathrm{N}_{2}, \mathrm{CH}_{4}\right.$, $\mathrm{CH}_{3}, \mathrm{CH}_{2}, \mathrm{CH}, \mathrm{C}_{2}, \mathrm{H}_{2}, \mathrm{CN}, \mathrm{NH}, \mathrm{HCN}, \mathrm{N}, \mathrm{C}, \mathrm{H}, \mathrm{N}_{2}^{+}, \mathrm{CN}^{+}$, $\mathrm{N}^{+}, \mathrm{C}^{+}$, and $\mathrm{e}^{-}$) and 28 reactions (Appendix $\mathrm{B}$ ). This model 


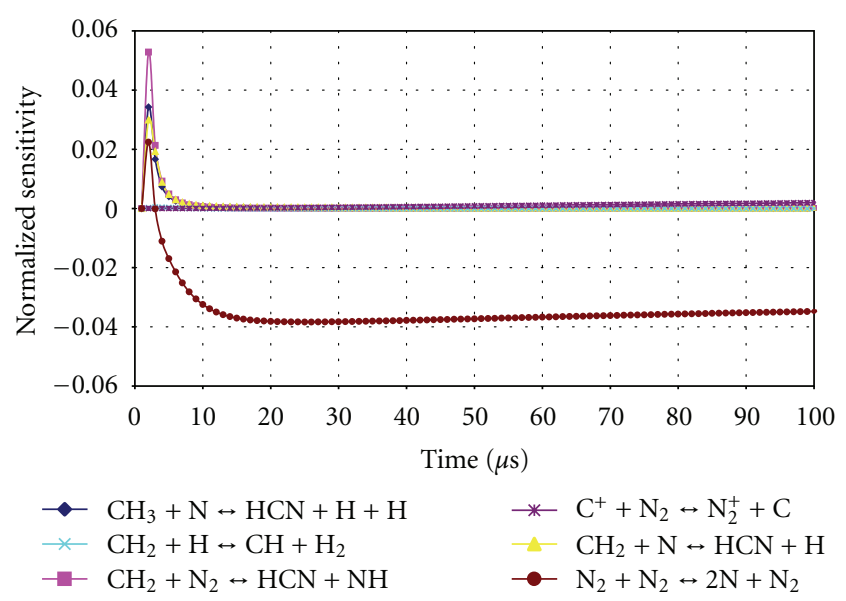

Figure 1: CN sensitivity coefficient.

was obtained following a two step analysis: first a comparison of the global equilibrium composition (time histories of the mole fractions) using CHEMKIN, second CFDs results were obtained comparing CFDs results on the geometry of the Huygens probe $[2,6]$. For the suppression of the reactions, the suggestion of Gökçen in his paper [4] was followed that is to remove the reactions $13,15,16,17$, and 35 of his model (Appendix A). A sensitivity analysis has also been performed for temperature and $\mathrm{CN}$ molar fractions to justify this choice. The suppression of the reactions numbered 32 and 33 is due to the removal of the species $\mathrm{H}^{+}, \mathrm{Ar}$, and $\mathrm{Ar}^{+}$. In Appendices $\mathrm{A}$ and $\mathrm{B}$, the parameter $F$ corresponds to the uncertainty factors as defined by Baulch et al. [7], the values are for most of them estimations provided by Gökçen [4] and should be considered as a lower limit on the uncertainty.

\section{Sensitivity Analysis}

Sensitivity coefficients of temperature and species moles fractions to the pre-exponential factor of kinetic equation $A$ were calculated. A sensitivity coefficient shows the influence of one parameter on another. It can be defined as

$$
S=\frac{\Delta x / x}{\Delta A / A}
$$

where $x$ is the temperature or a molar fraction and $A$ the preexponential factor. If its value is close to 0 , then there is no interaction between the two parameters. In Figures 1 and 2 are plotted the sensitivity coefficients of the temperature and the $\mathrm{CN}$ molar fraction for six reactions: the five we want to remove (i.e., nos. 13, 15, 16, 17, and 35) and the reaction (1) which is here for comparison. It is easily noticeable that the five first reactions do not impact on the molar fraction of $\mathrm{CN}$ and on the temperature.

Sensitivity analysis were also performed for $\mathrm{H}, \mathrm{C}, \mathrm{N}$, and $\mathrm{e}^{-}$but are not displayed here, as they gave similar results as above. These analyses were performed for only one set of initial conditions.

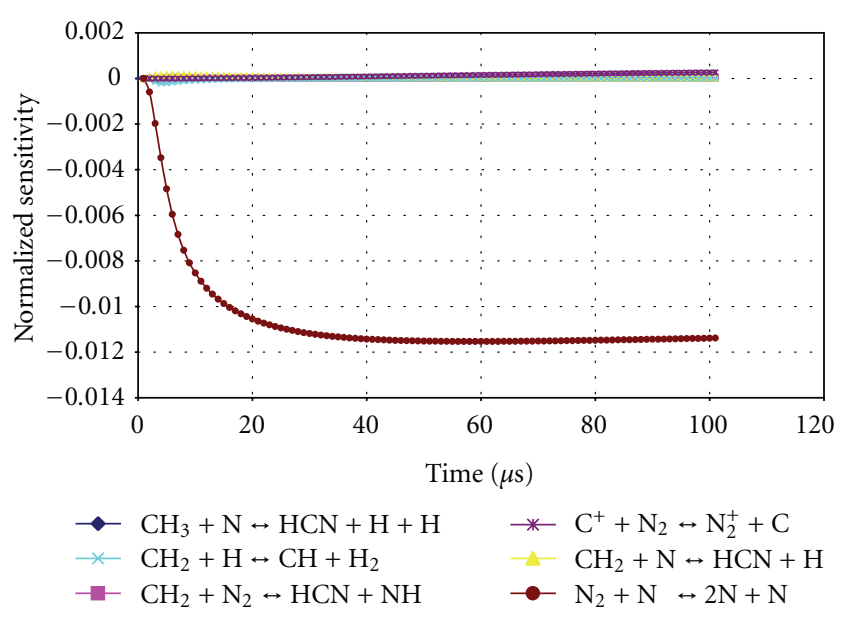

FIgURE 2: Temperature sensitivity coefficient.

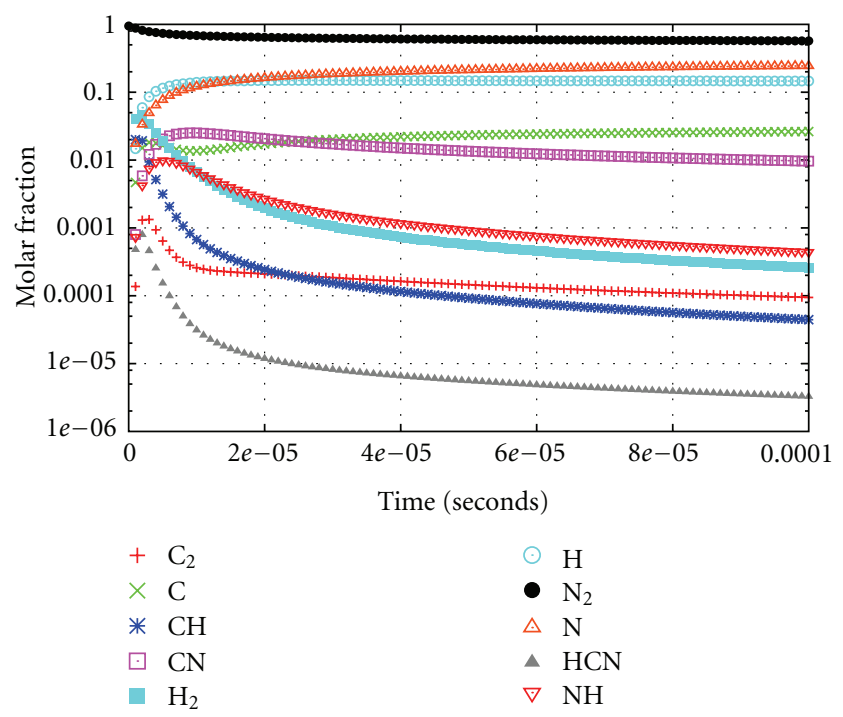

Figure 3: Neutrals-Gökçen's model.

\section{Simulations with CHEMKIN}

The first stage for the verification is a comparison of the evolution of the molar fractions between the reaction set of Gökçen given in Appendix A and the reduced one given in Appendix B. It was made using CHEMKIN with a simplified atmosphere of Titan, composed of $95 \%$ of $\mathrm{N}_{2}$ and $5 \%$ of $\mathrm{CH}_{4}$. The test case retained was a shock tube without boundary layer correction for an incident shock velocity of $6,300 \mathrm{~m} \cdot \mathrm{s}^{-1}$, a pressure of $0.1 \mathrm{Torr}$, and a temperature before shock of $300 \mathrm{~K}$. Thermodynamic data for species were calculated using 7 coefficient curve fits (old NASA form) obtained from the data generated with CEA 9 coefficient polynomials. The temperature range of verification is $300 \mathrm{~K}-2,000 \mathrm{~K}$. Besides, the downstream model equations assume that the flow is adiabatic and that transport phenomena (i.e., viscosity, thermal conduction, and mass diffusion) are negligible.

Time histories of molar fractions are plotted in Figures 3, 4, 5, and 6. Figures 3 and 4 show the neutrals and Figures 5 


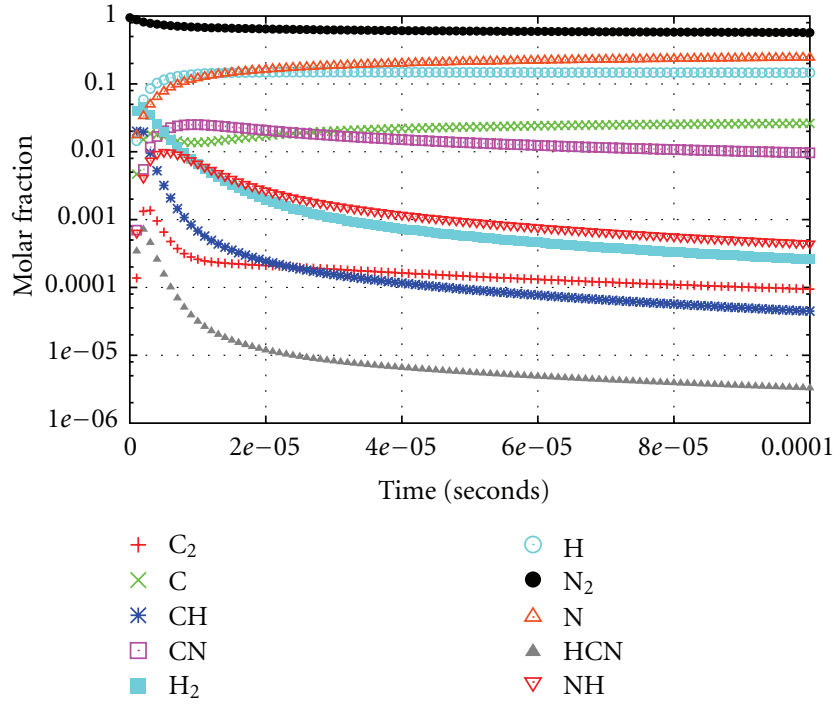

Figure 4: Neutrals-reduced model.

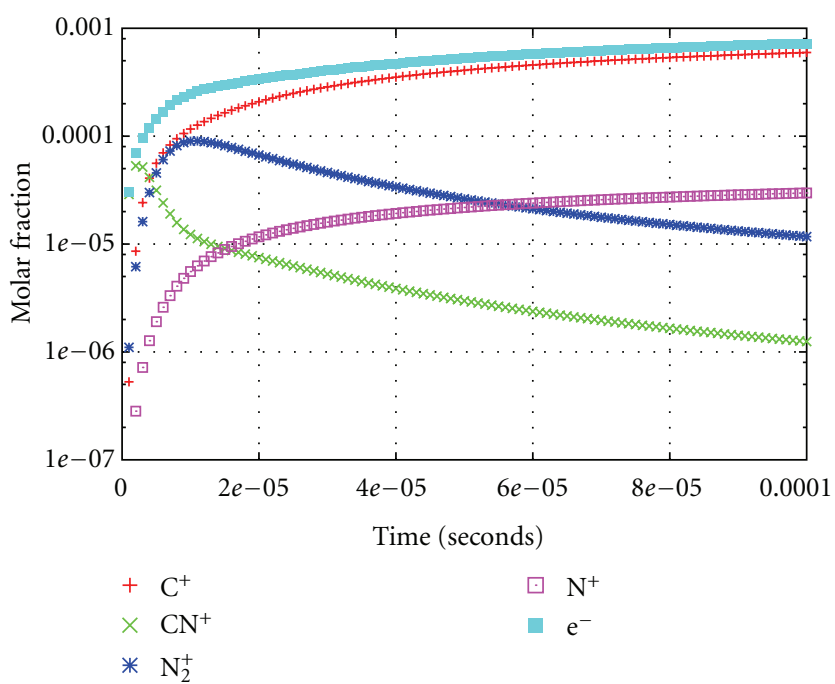

Figure 5: Ions-Gökçen's model.

and 6 the ions. The reduced model is matching almost exactly with Gökçen's model.

In Figure 7, a comparison for the $\mathrm{CN}$ molar fraction and for $T$ is plotted. Particular attention is given to the formation of $\mathrm{CN}$, as it is a strong radiator and the main contributor of the radiative heat flux encountered during Titan entry [8].

\section{Presentation of the Test Cases for the CFDs Code}

Three test cases $\left(\mathrm{TC}_{1}, \mathrm{TC}_{2}\right.$, and $\left.\mathrm{TC}_{3}\right)$ were retained for verification in the CFDs simulations. They were given and documented at the ESA Radiation Working Group Meetings [9]. The differences between them are the atmosphere composition and/or the chemical kinetic model. $\mathrm{TC}_{1}$ has been performed with an atmosphere composed of $94.3 \%$ of

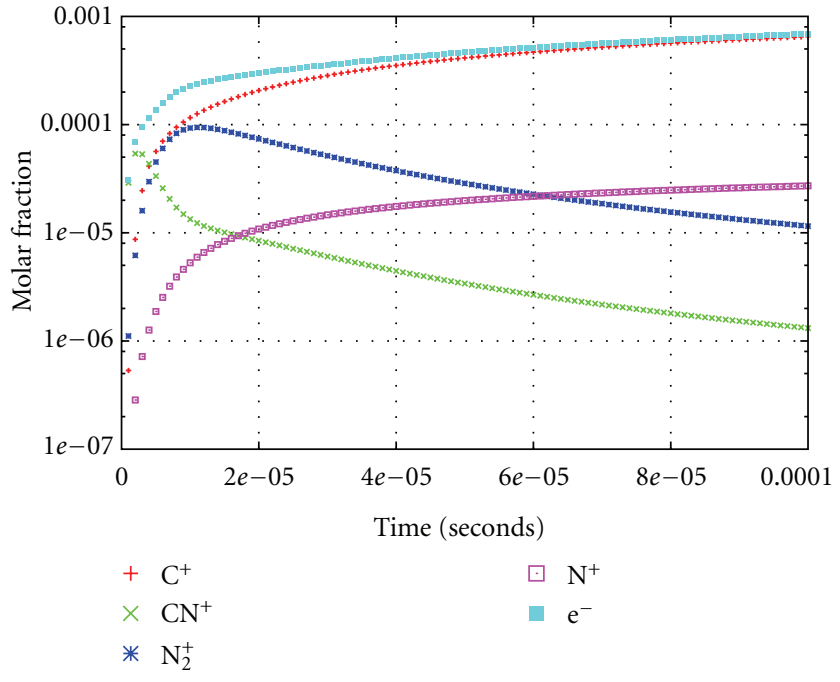

Figure 6: Ions-reduced model.

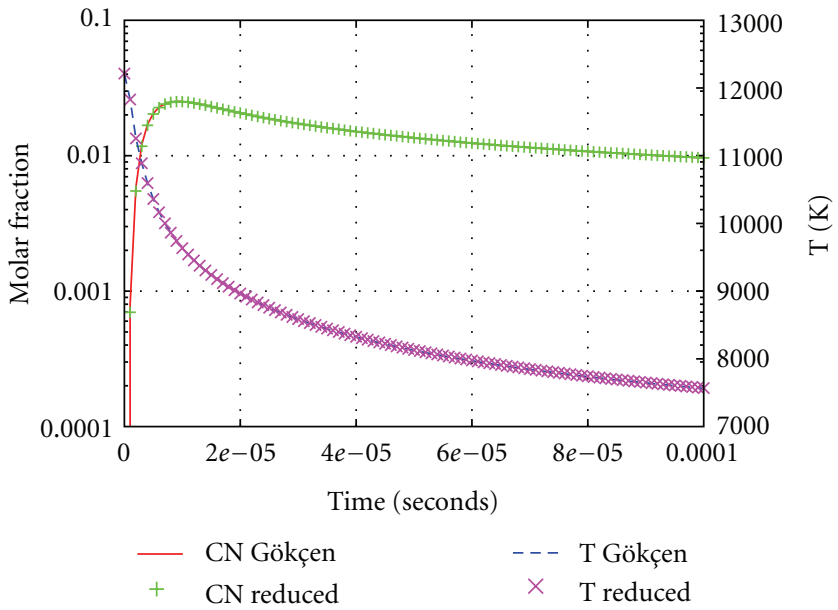

Figure 7: Comparison for CN molar fraction and $T$.

$\mathrm{N}_{2}, 5.0 \%$ of $\mathrm{CH}_{4}$, and $0.7 \%$ of Ar with the Gökçen chemical kinetic model. These values are determined so as to keep the same concentration of $\mathrm{CH}_{4}$ as in the Yelle minimal profile [10]. Indeed, the initial concentration of methane is decisive for the formation of $\mathrm{CN}$, which is a major criteria of the model verification. In $\mathrm{TC}_{2}$, the same reaction scheme was used, but it was with the minimal profile of Yelle atmosphere that is, $95.0 \%$ of $\mathrm{N}_{2}$ and $5.0 \%$ of $\mathrm{CH}_{4}$. The third test case, $\mathrm{TC}_{3}$, used the same atmosphere composition as $\mathrm{TC}_{2}$ but with the reduced chemical kinetic model.

The inflow conditions were the one corresponding to the peak heating of the Huygens probe [2]: velocity of $5126.3 \mathrm{~m} \cdot \mathrm{s}^{-1}$, density of $2.96 \times 10^{-4}$, and temperature of $176.6 \mathrm{~K}$ (trajectory point: $t=189 \mathrm{~s}$ ).

The test cases were performed on the Huygens probe geometry [6]. It is a $60^{\circ}$ half angle blunted cone with a base diameter of $2.7 \mathrm{~m}$ and a nose radius of $1.25 \mathrm{~m}$. To mesh the domain, 80 nodes are used in both axial and radial directions. 
TABLE 1: Shock standoff distance $(\mathrm{cm})$.

\begin{tabular}{lcc}
\hline $\mathrm{TC}_{1}$ & $\mathrm{TC}_{2}$ & $\mathrm{TC}_{3}$ \\
\hline $9.6 \pm 0.3$ & $9.7 \pm 0.3$ & $9.6 \pm 0.3$ \\
\hline
\end{tabular}

\section{CFDs Simulations}

The CFDs code used for the simulations is based on the MB_CNS tool developed at the University of Queensland, Hypersonics Centre, Australia. It is a software for the simulation of transient compressible flow in 2D, based on a finite volume formulation of the Navier-Stokes equations. Radiation modelisation has been implemented recently [9]. For the computation of viscosity and thermal conductivity of each species, curve fits from McBride and Gordon [11] are used

$$
\begin{aligned}
& \log \mu(T)=a_{0} \log T+\frac{a_{1}}{T}+\frac{a_{2}}{T^{2}}+a_{3}, \\
& \log k(T)=b_{0} \log T+\frac{b_{1}}{T}+\frac{b_{2}}{T^{2}}+b_{3} .
\end{aligned}
$$

The values for the coefficients are available in the CEA program developed by NASA. The mixing rules used are a variant of Wilke's original formulation [12], they have been developed by Gordon and McBride [13]

$$
\begin{aligned}
& \mu_{\text {mix }}=\sum_{i=1}^{N} \frac{x_{i} \mu_{i}}{x_{i}+\sum_{j=1, j \neq i}^{N} x_{j} \phi_{i j}}, \\
& k_{\text {mix }}=\sum_{i=1}^{N} \frac{x_{i} k_{i}}{x_{i}+\sum_{j=1, j \neq i}^{N} x_{j} \psi_{i j}},
\end{aligned}
$$

where $x_{i}$ is the mole fraction of species $i . \phi_{i}$ and $\psi_{i}$ are interaction potentials, they are calculated using once again the formulation of Gordon and McBride [13]

$$
\begin{aligned}
& \phi_{i j}=\frac{1}{4}\left[1+\left(\frac{\mu_{i}}{\mu_{j}}\right)^{1 / 2}\left(\frac{M_{j}}{M_{i}}\right)^{1 / 4}\right]^{2}\left(\frac{2 M_{j}}{M_{i}+M_{j}}\right)^{1 / 2}, \\
& \psi_{i j}=\phi_{i j}\left[1+\frac{2.41\left(M_{i}-M_{j}\right)\left(M_{i}-0.142 M_{j}\right)}{\left(M_{i}+M_{j}\right)^{2}}\right] .
\end{aligned}
$$

Among all the radiation models implemented, the discrete transfer method was chosen to perform the computations, since data for Titan were readily available, and it was not too time consuming. The radiating species were $\mathrm{CN}$ (Violet and Red), $\mathrm{N}_{2}$ (first positive and second positive), and $\mathrm{C}_{2}$ (Swan). Parameters of the radiation model were taken

(i) $\lambda_{\min }=250 \mathrm{~nm}$,

(ii) $\lambda_{\max }=2000 \mathrm{~nm}$,

(iii) spectral points $=1751$,

(iv) number of rays $=32$,

(v) electronic states in nonequilibrium.

The number of spectral points is quite small as we are using the smeared rotational band (SRB) method to
TABLE 2: Heat fluxes comparison $\left(\mathrm{W} / \mathrm{cm}^{2}\right)$.

\begin{tabular}{lccc}
\hline & $\mathrm{TC}_{1}$ & $\mathrm{TC}_{2}$ & $\mathrm{TC}_{3}$ \\
\hline Conductive & 19 & 32 & 32 \\
Radiative & 49 & 50 & 49 \\
\hline Total & 68 & 82 & 81 \\
\hline
\end{tabular}

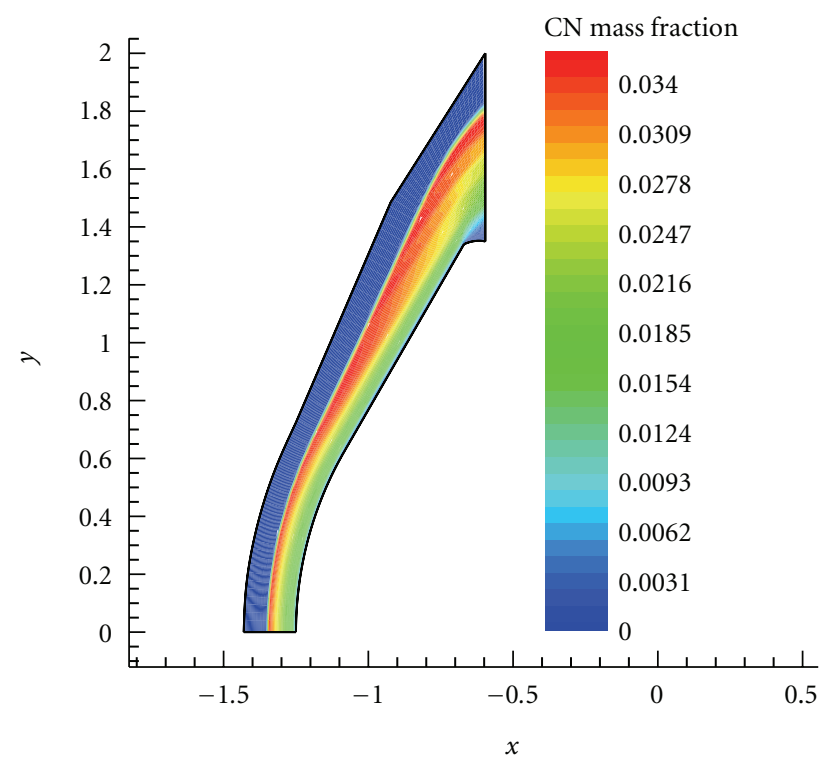

FIgURE 8: CN mass fraction- $\mathrm{TC}_{1}$.

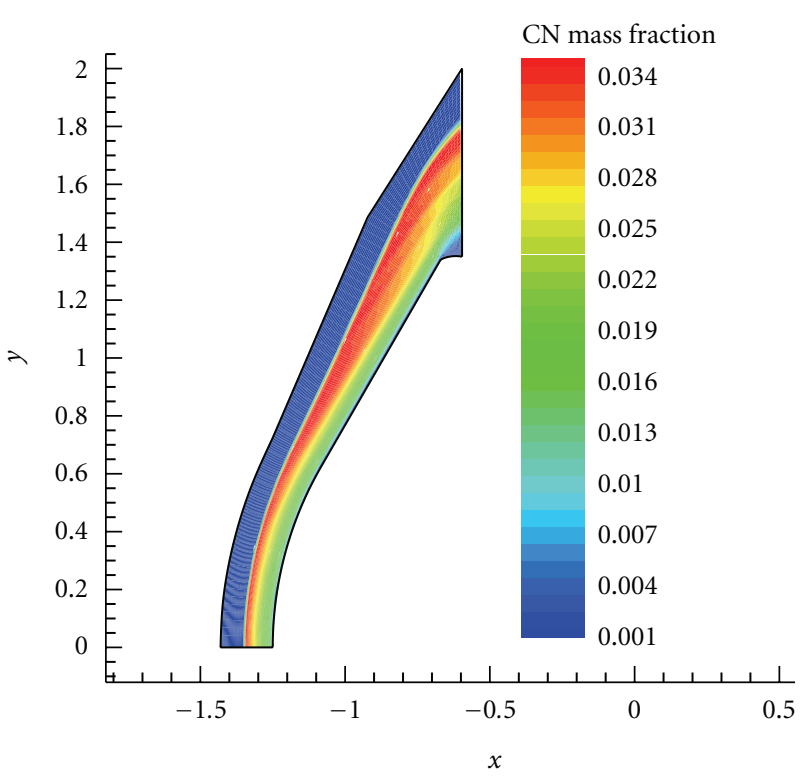

FIgURE 9: $\mathrm{CN}$ mass fraction- $\mathrm{TC}_{3}$.

determine the spectra and not a line-by-line model. Using a line-by-line model with a discrete transfer method would be more time consuming.

The first criteria of good agreement between the models is the shock standoff distance. As shown in Table 1, the shock standoff distance in not affected by the removal of $\mathrm{Ar} \mathrm{Ar}^{+}$, and $\mathrm{H}^{+}$, nor by the reduced kinetic scheme. 
TABLE 3

\begin{tabular}{|c|c|c|c|c|c|}
\hline & $k_{f}=A T^{n} \mathrm{e}^{-T_{a} / T}$ & $A, \mathrm{cc} / \mathrm{mol} / \mathrm{s}$ & $n$ & $T_{a}, \mathrm{~K}$ & Source Uncert. est. \\
\hline \multicolumn{6}{|c|}{ Dissociation reactions } \\
\hline \multirow[t]{3}{*}{ (1) } & $\mathrm{N}_{2}+\mathrm{M} \leftrightarrows \mathrm{N}+\mathrm{N}+\mathrm{M}$ & $7.00 \times 10^{21}$ & -1.60 & 113,200 & {$[14] / F=3.0$} \\
\hline & Enhanced rate for $\mathrm{M}=\mathrm{N}, \mathrm{C}, \mathrm{H}$ & $3.00 \times 10^{22}$ & -1.60 & 113,200 & {$[14] / F=3.0-5.0$} \\
\hline & Enhanced rate for $\mathrm{M}=\mathrm{e}^{-}$ & $3.00 \times 10^{24}$ & -1.60 & 113,200 & {$[14] / F=3.0$} \\
\hline (2) & $\mathrm{CH}_{4}+\mathrm{M} \leftrightarrows \mathrm{CH}_{3}+\mathrm{H}+\mathrm{M}$ & $4.70 \times 10^{47}$ & -8.20 & 59,200 & {$[7] / F=2.0$} \\
\hline (3) & $\mathrm{CH}_{3}+\mathrm{M} \leftrightarrows \mathrm{CH}_{2}+\mathrm{H}+\mathrm{M}$ & $1.02 \times 10^{16}$ & 0.00 & 45,600 & {$[7] / F=1.26-3.2$} \\
\hline (4) & $\mathrm{CH}_{3}+\mathrm{M} \leftrightarrows \mathrm{CH}+\mathrm{H}_{2}+\mathrm{M}$ & $5.00 \times 10^{15}$ & 0.00 & 42,800 & {$[15] / F=1.26-2.0$} \\
\hline (5) & $\mathrm{CH}_{2}+\mathrm{M} \leftrightarrows \mathrm{CH}+\mathrm{H}+\mathrm{M}$ & $4.00 \times 10^{15}$ & 0.00 & 41,800 & {$[15] / F=1.26-2.0$} \\
\hline (6) & $\mathrm{CH}_{2}+\mathrm{M} \leftrightarrows \mathrm{C}+\mathrm{H}_{2}+\mathrm{M}$ & $1.30 \times 10^{14}$ & 0.00 & 29,700 & {$[15] / F=1.26-2.0$} \\
\hline (7) & $\mathrm{CH}+\mathrm{M} \leftrightarrows \mathrm{C}+\mathrm{H}+\mathrm{M}$ & $1.90 \times 10^{14}$ & 0.00 & 33,700 & {$[15] / F=1.26-2.0$} \\
\hline (8) & $\mathrm{C}_{2}+\mathrm{M} \leftrightarrows \mathrm{C}+\mathrm{C}+\mathrm{M}$ & $1.50 \times 10^{16}$ & 0.00 & 71,600 & {$[16] / F=1.26-2.0$} \\
\hline (9) & $\mathrm{H}_{2}+\mathrm{M} \leftrightarrows \mathrm{H}+\mathrm{H}+\mathrm{M}$ & $2.23 \times 10^{14}$ & 0.00 & 48,350 & {$[7,17] / F=1.26-2.0$} \\
\hline$(10)$ & $\mathrm{CN}+\mathrm{M} \leftrightarrows \mathrm{C}+\mathrm{N}+\mathrm{M}$ & $2.53 \times 10^{14}$ & 0.00 & 71,000 & {$[18,19] / F=1.5-2.0$} \\
\hline (11) & $\mathrm{NH}+\mathrm{M} \leftrightarrows \mathrm{N}+\mathrm{H}+\mathrm{M}$ & $1.80 \times 10^{14}$ & 0.00 & 37,600 & {$[20] / F=1.26--2.0$} \\
\hline (12) & $\mathrm{HCN}+\mathrm{M} \leftrightarrows \mathrm{CN}+\mathrm{H}+\mathrm{M}$ & $3.57 \times 10^{26}$ & -2.60 & 62,845 & {$[21] / F=1.5--2.0$} \\
\hline \multicolumn{6}{|c|}{ Radical reactions } \\
\hline (13) & $\mathrm{CH}_{3}+\mathrm{N} \leftrightarrows \mathrm{HCN}+\mathrm{H}+\mathrm{H}$ & $7.00 \times 10^{13}$ & 0.00 & 0 & {$[22] / F=10.0$} \\
\hline (14) & $\mathrm{CH}_{3}+\mathrm{H} \leftrightarrows \mathrm{CH}_{2}+\mathrm{H}_{2}$ & $6.03 \times 10^{13}$ & 0.00 & 7,600 & {$[17] / F=10.0$} \\
\hline (15) & $\mathrm{CH}_{2}+\mathrm{N}_{2} \leftrightarrows \mathrm{HCN}+\mathrm{NH}$ & $4.82 \times 10^{12}$ & 0.00 & 18,000 & {$[20] / F=10.0$} \\
\hline (16) & $\mathrm{CH}_{2}+\mathrm{N} \leftrightarrows \mathrm{HCN}+\mathrm{H}$ & $5.00 \times 10^{13}$ & 0.00 & 0 & {$[22] / F=10.0$} \\
\hline (17) & $\mathrm{CH}_{2}+\mathrm{H} \leftrightarrows \mathrm{CH}+\mathrm{H}_{2}$ & $6.03 \times 10^{12}$ & 0.00 & -900 & {$[20] / F=5.0-10.0$} \\
\hline (18) & $\mathrm{CH}+\mathrm{N}_{2} \leftrightarrows \mathrm{HCN}+\mathrm{N}$ & $4.40 \times 10^{12}$ & 0.00 & 11,060 & {$[22] / F=1.5--3.2$} \\
\hline (19) & $\mathrm{CH}+\mathrm{C} \leftrightarrows \mathrm{C}_{2}+\mathrm{H}$ & $2.00 \times 10^{14}$ & 0.00 & 0 & {$[15] / F=10.0$} \\
\hline$(20)$ & $\mathrm{C}_{2}+\mathrm{N}_{2} \leftrightarrows \mathrm{CN}+\mathrm{CN}$ & $1.50 \times 10^{13}$ & 0.00 & 21,000 & {$[23] / F=1.26-2.0$} \\
\hline$(21)$ & $\mathrm{CN}+\mathrm{H}_{2} \leftrightarrows \mathrm{HCN}+\mathrm{H}$ & $2.95 \times 10^{5}$ & 0.00 & 1,130 & {$[24] / F=3.2--5.0$} \\
\hline (22) & $\mathrm{CN}+\mathrm{C} \leftrightarrows \mathrm{C}_{2}+\mathrm{N}$ & $5.00 \times 10^{13}$ & 0.00 & 13,000 & {$[14] / F=2.0--5.0$} \\
\hline (23) & $\mathrm{N}+\mathrm{H}_{2} \leftrightarrows \mathrm{NH}+\mathrm{H}$ & $1.60 \times 10^{14}$ & 0.00 & 12,650 & {$[25] / F=1.26-2.0$} \\
\hline$(24)$ & $\mathrm{C}+\mathrm{N}_{2} \leftrightarrows \mathrm{CN}+\mathrm{N}$ & $5.24 \times 10^{13}$ & 0.00 & 22,600 & {$[7] / F=1.6--2.0$} \\
\hline$(25)$ & $\mathrm{C}+\mathrm{H}_{2} \leftrightarrows \mathrm{CH}+\mathrm{H}$ & $4.00 \times 10^{14}$ & 0.00 & 11,700 & {$[26] / F=1.6-2.0$} \\
\hline (26) & $\mathrm{H}+\mathrm{N}_{2} \leftrightarrows \mathrm{NH}+\mathrm{N}$ & $3.00 \times 10^{12}$ & 0.50 & 71,400 & {$[27] / F=2.0-3.2$} \\
\hline (27) & $\mathrm{H}+\mathrm{CH}_{4} \leftrightarrows \mathrm{CH}_{3}+\mathrm{H}_{2}$ & $1.32 \times 10^{4}$ & 3.00 & 4,045 & {$[7,17] / F=1.6-2.0$} \\
\hline \multicolumn{6}{|c|}{ Ionization reactions } \\
\hline$(28)$ & $\mathrm{N}+\mathrm{N} \leftrightarrows \mathrm{N}_{2}^{+}+\mathrm{e}^{-}$ & $4.40 \times 10^{7}$ & 1.50 & 67,500 & {$[14] / F=10.0$} \\
\hline (29) & $\mathrm{C}+\mathrm{N} \leftrightarrows \mathrm{CN}^{+}+\mathrm{e}^{-}$ & $1.00 \times 10^{15}$ & 1.50 & 164,400 & {$[1] / F \geq 10.0$} \\
\hline$(30)$ & $\mathrm{N}+\mathrm{e}^{-} \leftrightarrows \mathrm{N}^{+}+\mathrm{e}^{-}+\mathrm{e}^{-}$ & $2.50 \times 10^{34}$ & -3.82 & 168,600 & {$[14,28] / F=10.0$} \\
\hline$(31)$ & $\mathrm{C}+\mathrm{e}^{-} \leftrightarrows \mathrm{C}^{+}+\mathrm{e}^{-}+\mathrm{e}^{-}$ & $3.70 \times 10^{31}$ & -3.00 & 130,720 & {$[14] / F=10.0$} \\
\hline (32) & $\mathrm{H}+\mathrm{e}^{-} \leftrightarrows \mathrm{H}^{+}+\mathrm{e}^{-}+\mathrm{e}^{-}$ & $2.20 \times 10^{30}$ & -2.80 & 157,800 & {$[14] / F \geq 10.0$} \\
\hline (33) & $\mathrm{Ar}+\mathrm{e}^{-} \leftrightarrows \mathrm{Ar}^{+}+\mathrm{e}^{-}+\mathrm{e}^{-}$ & $2.50 \times 10^{34}$ & -3.82 & 181,700 & {$[1] / F \geq 10.0$} \\
\hline$(34)$ & $\mathrm{CN}^{+}+\mathrm{N} \leftrightarrows \mathrm{CN}+\mathrm{N}^{+}$ & $9.80 \times 10^{12}$ & 0.00 & 40,700 & {$[1] / F \geq 10.0$} \\
\hline$(35)$ & $\mathrm{C}^{+}+\mathrm{N}_{2} \leftrightarrows \mathrm{N}_{2}^{+}+\mathrm{C}$ & $1.11 \times 10^{14}$ & -0.11 & 50,000 & {$[1] / F \geq 10.0$} \\
\hline
\end{tabular}

As $\mathrm{CN}$ is the main radiator, it is crucial that the new reduced model $\left(\mathrm{TC}_{3}\right)$ gives the same $\mathrm{CN}$ concentrations as $\mathrm{TC}_{1}$.

Figures 8 and 9 show that the $\mathrm{CN}$ distribution is very close; consequently, the radiative flux obtained in both cases should be similar as well. Temperature profiles among the stagnation line are displayed in Figure 10. For $\mathrm{TC}_{3}$, the temperature peak is a slightly higher and sharper due to the removal of Ar. In Figure 11, it can be noticed that in $\mathrm{TC}_{1}$, the wall temperature is lower, this will lead to a lower conductive heat flux as well.

In Table 2, values obtained for the different components of the total heat flux are summarised.

As predicted, the conductive heat flux is smaller for $\mathrm{TC}_{1}$. However, the uncertainties on the heat fluxes are about $5 \mathrm{~W} / \mathrm{cm}^{2}$; consequently, they can be considered to be in the 
TABLE 4

\begin{tabular}{|c|c|c|c|c|c|}
\hline & $k_{f}=A T^{n} \mathrm{e}^{-T_{a} / T}$ & $A, \mathrm{cc} / \mathrm{mol} / \mathrm{s}$ & $n$ & $T_{a}, \mathrm{~K}$ & Source Uncert. est. \\
\hline \multicolumn{6}{|c|}{ Dissociation reactions } \\
\hline \multirow[t]{3}{*}{ (1) } & $\mathrm{N}_{2}+\mathrm{M} \leftrightarrows \mathrm{N}+\mathrm{N}+\mathrm{M}$ & $7.00 \times 10^{21}$ & -1.60 & 113,200 & {$[14] / F=3.0$} \\
\hline & Enhanced rate for $\mathrm{M}=\mathrm{N}, \mathrm{C}, \mathrm{H}$ & $3.00 \times 10^{22}$ & -1.60 & 113,200 & {$[14] / F=3.0-5.0$} \\
\hline & Enhanced rate for $\mathrm{M}=\mathrm{e}^{-}$ & $3.00 \times 10^{24}$ & -1.60 & 113,200 & {$[14] / F=3.0$} \\
\hline (2) & $\mathrm{CH}_{4}+\mathrm{M} \leftrightarrows \mathrm{CH}_{3}+\mathrm{H}+\mathrm{M}$ & $4.70 \times 10^{47}$ & -8.20 & 59,200 & {$[7] / F=2.0$} \\
\hline (3) & $\mathrm{CH}_{3}+\mathrm{M} \leftrightarrows \mathrm{CH}_{2}+\mathrm{H}+\mathrm{M}$ & $1.02 \times 10^{16}$ & 0.00 & 45,600 & {$[7] / F=1.26-3.2$} \\
\hline (4) & $\mathrm{CH}_{3}+\mathrm{M} \leftrightarrows \mathrm{CH}+\mathrm{H}_{2}+\mathrm{M}$ & $5.00 \times 10^{15}$ & 0.00 & 42,800 & {$[15] / F=1.26-2.0$} \\
\hline (5) & $\mathrm{CH}_{2}+\mathrm{M} \leftrightarrows \mathrm{CH}+\mathrm{H}+\mathrm{M}$ & $4.00 \times 10^{15}$ & 0.00 & 41,800 & {$[15] / F=1.26-2.0$} \\
\hline (6) & $\mathrm{CH}_{2}+\mathrm{M} \leftrightarrows \mathrm{C}+\mathrm{H}_{2}+\mathrm{M}$ & $1.30 \times 10^{14}$ & 0.00 & 29,700 & {$[15] / F=1.26-2.0$} \\
\hline (7) & $\mathrm{CH}+\mathrm{M} \leftrightarrows \mathrm{C}+\mathrm{H}+\mathrm{M}$ & $1.90 \times 10^{14}$ & 0.00 & 33,700 & {$[15] / F=1.26-2.0$} \\
\hline (8) & $\mathrm{C}_{2}+\mathrm{M} \leftrightarrows \mathrm{C}+\mathrm{C}+\mathrm{M}$ & $1.50 \times 10^{16}$ & 0.00 & 71,600 & {$[16] / F=1.26-2.0$} \\
\hline (9) & $\mathrm{H}_{2}+\mathrm{M} \leftrightarrows \mathrm{H}+\mathrm{H}+\mathrm{M}$ & $2.23 \times 10^{14}$ & 0.00 & 48,350 & {$[7,17] / F=1.26-2.0$} \\
\hline (10) & $\mathrm{CN}+\mathrm{M} \leftrightarrows \mathrm{C}+\mathrm{N}+\mathrm{M}$ & $2.53 \times 10^{14}$ & 0.00 & 71,000 & {$[18,19] / F=1.5-2.0$} \\
\hline (11) & $\mathrm{NH}+\mathrm{M} \leftrightarrows \mathrm{N}+\mathrm{H}+\mathrm{M}$ & $1.80 \times 10^{14}$ & 0.00 & 37,600 & {$[20] / F=1.26--2.0$} \\
\hline$(12)$ & $\mathrm{HCN}+\mathrm{M} \leftrightarrows \mathrm{CN}+\mathrm{H}+\mathrm{M}$ & $3.57 \times 10^{26}$ & -2.60 & 62,845 & {$[21] / F=1.5-2.0$} \\
\hline \multicolumn{6}{|c|}{ Radical reactions } \\
\hline (13) & $\mathrm{CH}_{3}+\mathrm{H} \leftrightarrows \mathrm{CH}_{2}+\mathrm{H}_{2}$ & $6.03 \times 10^{13}$ & 0.00 & 7,600 & {$[17] / F=10.0$} \\
\hline (14) & $\mathrm{CH}+\mathrm{N}_{2} \leftrightarrows \mathrm{HCN}+\mathrm{N}$ & $4.40 \times 10^{12}$ & 0.00 & 11,060 & {$[22] / F=1.5-3.2$} \\
\hline (15) & $\mathrm{CH}+\mathrm{C} \leftrightarrows \mathrm{C}_{2}+\mathrm{H}$ & $2.00 \times 10^{14}$ & 0.00 & 0 & {$[15] / F=10.0$} \\
\hline (16) & $\mathrm{C}_{2}+\mathrm{N}_{2} \leftrightarrows \mathrm{CN}+\mathrm{CN}$ & $1.50 \times 10^{13}$ & 0.00 & 21,000 & {$[23] / F=1.26-2.0$} \\
\hline (17) & $\mathrm{CN}+\mathrm{H}_{2} \leftrightarrows \mathrm{HCN}+\mathrm{H}$ & $2.95 \times 10^{5}$ & 0.00 & 1,130 & {$[24] / F=3.2-5.0$} \\
\hline (18) & $\mathrm{CN}+\mathrm{C} \leftrightarrows \mathrm{C}_{2}+\mathrm{N}$ & $5.00 \times 10^{13}$ & 0.00 & 13,000 & {$[14] / F=2.0-5.0$} \\
\hline (19) & $\mathrm{N}+\mathrm{H}_{2} \leftrightarrows \mathrm{NH}+\mathrm{H}$ & $1.60 \times 10^{14}$ & 0.00 & 12,650 & {$[25] / F=1.26-2.0$} \\
\hline (20) & $\mathrm{C}+\mathrm{N}_{2} \leftrightarrows \mathrm{CN}+\mathrm{N}$ & $5.24 \times 10^{13}$ & 0.00 & 22,600 & {$[7] / F=1.6-2.0$} \\
\hline$(21)$ & $\mathrm{C}+\mathrm{H}_{2} \leftrightarrows \mathrm{CH}+\mathrm{H}$ & $4.00 \times 10^{14}$ & 0.00 & 11,700 & {$[26] / F=1.6-2.0$} \\
\hline (22) & $\mathrm{H}+\mathrm{N}_{2} \leftrightarrows \mathrm{NH}+\mathrm{N}$ & $3.00 \times 10^{12}$ & 0.50 & 71,400 & {$[27] / F=2.0-3.2$} \\
\hline (23) & $\mathrm{H}+\mathrm{CH}_{4} \leftrightarrows \mathrm{CH}_{3}+\mathrm{H}_{2}$ & $1.32 \times 10^{4}$ & 3.00 & 4,045 & {$[7,17] / F=1.6-2.0$} \\
\hline \multicolumn{6}{|c|}{ Ionization reactions } \\
\hline$(24)$ & $\mathrm{N}+\mathrm{N} \leftrightarrows \mathrm{N}_{2}^{+}+\mathrm{e}^{-}$ & $4.40 \times 10^{7}$ & 1.50 & 67,500 & {$[14] / F=10.0$} \\
\hline (25) & $\mathrm{C}+\mathrm{N} \leftrightarrows \mathrm{CN}^{+}+\mathrm{e}^{-}$ & $1.00 \times 10^{15}$ & 1.50 & 164,400 & {$[1] / F \geq 10.0$} \\
\hline (26) & $\mathrm{N}+\mathrm{e}^{-} \leftrightarrows \mathrm{N}^{+}+\mathrm{e}^{-}+\mathrm{e}^{-}$ & $2.50 \times 10^{34}$ & -3.82 & 168,600 & {$[14,28] / F=10.0$} \\
\hline (27) & $\mathrm{C}+\mathrm{e}^{-} \leftrightarrows \mathrm{C}^{+}+\mathrm{e}^{-}+\mathrm{e}^{-}$ & $3.70 \times 10^{31}$ & -3.00 & 130,720 & {$[14] / F=10.0$} \\
\hline (28) & $\mathrm{CN}^{+}+\mathrm{N} \leftrightarrows \mathrm{CN}+\mathrm{N}^{+}$ & $9.80 \times 10^{12}$ & 0.00 & 40,700 & {$[1] / F \geq 10.0$} \\
\hline
\end{tabular}

same order of magnitude. It is also noticeable that the values for the radiative fluxes are in good agreement with other results in the literature [12].

\section{Conclusions}

This new reduced model including only 18 species $\left(\mathrm{N}_{2}, \mathrm{CH}_{4}\right.$, $\mathrm{CH}_{3}, \mathrm{CH}_{2}, \mathrm{CH}, \mathrm{C}_{2}, \mathrm{H}_{2}, \mathrm{CN}, \mathrm{NH}, \mathrm{HCN}, \mathrm{N}, \mathrm{C}, \mathrm{H}, \mathrm{N}_{2}^{+}, \mathrm{CN}^{+}$, $\mathrm{N}^{+}, \mathrm{C}^{+}$, and $\mathrm{e}^{-}$) and 28 reactions (instead of 35 ) is in very good agreement with the kinetic reaction set developed by Gökçen. The distribution of $\mathrm{CN}$, main radiator, is almost identical as the full model. As for the heat fluxes, the order of magnitude is the same even though the conductive heat flux is higher in $\mathrm{TC}_{3}$ due to the removal of Ar which can reduce the electronic temperature. Attempts were also made to reduce further this model, like for example the removal of $\mathrm{C}^{+}$. This, however, leads to huge discrepancies in the molar fractions of charged particles especially for electrons.

\section{Appendices}

\section{A. Gökçen Chemical Reaction Set for $\mathbf{N}_{2}-\mathbf{C H}_{4}$-Ar Mixtures}

See Table 3.

\section{B. Reduced Chemical Reaction Set for $\mathrm{N}_{2}-\mathrm{CH}_{4}-\mathbf{A r}$ Mixtures}

See Table 4. 


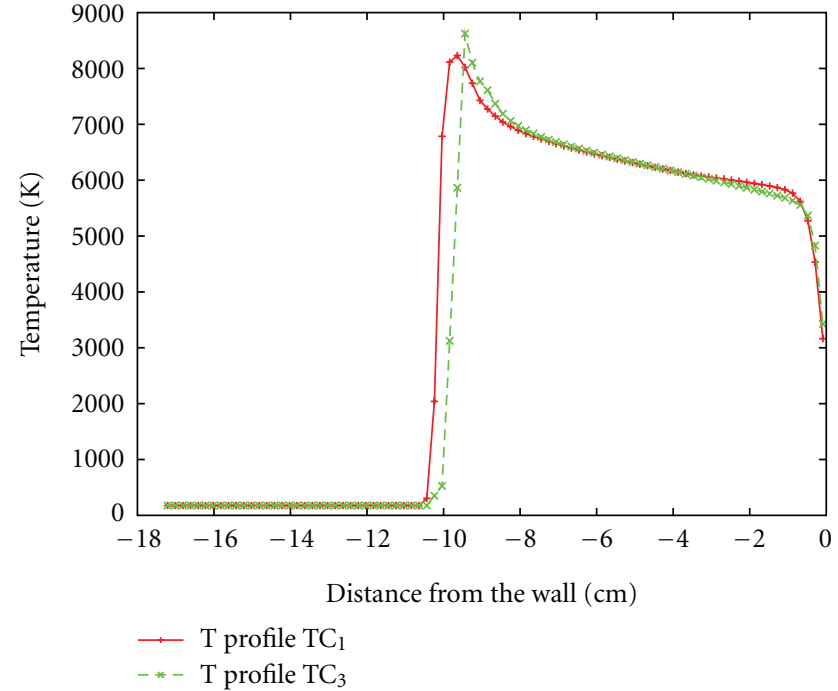

FIgURE 10: Temperature profiles among stagnation line for $\mathrm{TC}_{1}$ and $\mathrm{TC}_{3}$.

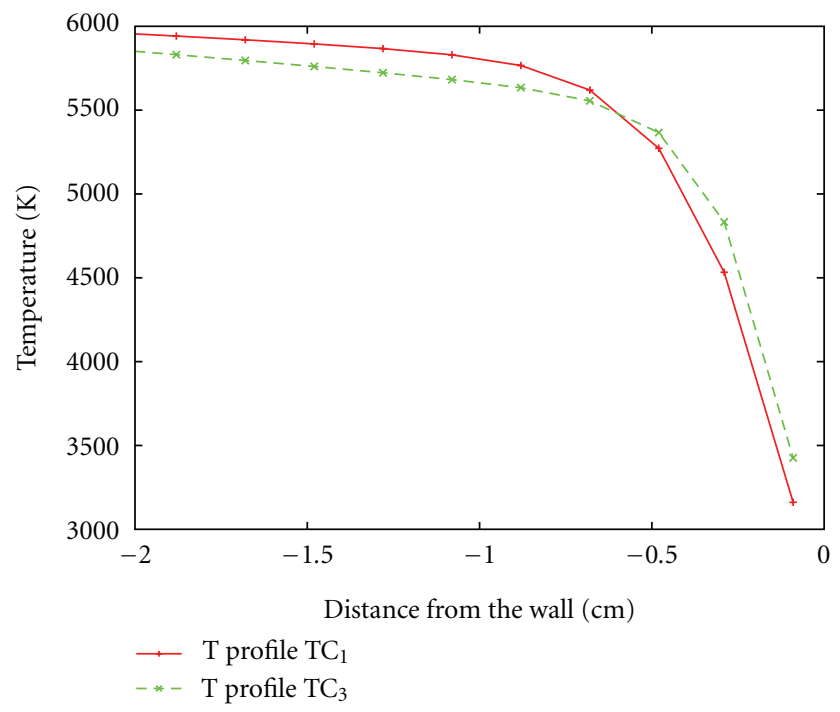

Figure 11: Detailled temperature profiles among stagnation line for $\mathrm{TC}_{1}$ and $\mathrm{TC}_{3}$.

\section{Acknowledgment}

This work was partially supported by the ESA-NPI Program, and CCN C21872.

\section{References}

[1] H. F. Nelson, C. Park, and E. E. Whiting, "Titan atmospheric composition by hypervelocity shock-layer analysis," Journal of Thermophysics and Heat Transfer, vol. 5, no. 2, pp. 157-165, 1991.

[2] H. Osawa, S. Matsuyama, N. Ohnishi, M. Furudate, and K. Sawada, "Numerical computation of radiative heating environment for huygens probe entry flight," Journal of Thermophysics and Heat Transfer, vol. 22, no. 2, pp. 140-149, 2008.
[3] M. J. Wright, D. Bose, and J. Olejniczak, "The impact of flowfield-radiation coupling on aeroheating for Titan aerocapture," in Proceedings of the 42nd AIAA Aerospace Sciences Meeting and Exhibit, Reno, Nev, USA, 2004.

[4] T. Gökçen, "N $\mathrm{N}_{2}-\mathrm{CH}_{4}-\mathrm{Ar}$ chemical kinetic model for simulations of Titan atmospheric entry," Journal of Thermo-physics and Heat Transfer, vol. 21, no. 1, pp. 9-18, 2007.

[5] P. Leyland, R. Sobbia, and J. B. Vos, "Chemical kinetic and radiating species studies of Titan aerocapture entry," in Proceedings of the 16th Australian Fluid Mechanics Conference, Australia, 2007.

[6] F. Mazoue and L. Marraffa, "Flow-field/radiation coupling analysis for huygens probe entry into Titan atmosphere," in Proceedings of the 38th AIAA Thermophysics Conference, Toronto, Canada, June 2005.

[7] D. L. Baulch, C. J. Cobos, R. A. Cox et al., "Evaluated kinetic data for combustion modelling, supplement I," Journal of Physical Chemistry Reference Data, vol. 26, no. 6, pp. 847-1033, 1994.

[8] D. Bose, M. J. Wright, D. W. Bogdanoff, G. A. Raiche, and G. A. Allen Jr., "Modeling and experimental assessment of $\mathrm{CN}$ radiation behind a strong shock wave," Journal of Thermophysics and Heat Transfer, vol. 20, no. 2, pp. 220-230, 2006.

[9] D. Potter, S. Karl, and P. Leyland, "TN032-EPFL contribution to ESA-TRP AMOD,” Tech. Rep., ESA, 2009.

[10] R. V. Yelle, D. F. Strobell, E. Lellouch, and D. Gautier, "Engineering models for Titan's atmosphere," ESA SP-1177, pp. 243-256, 1997.

[11] B. J. McBride and S. Gordon, "Computer program for calculation of complex chemical equilibrium compositions and applications. Part 2: users manual and program description. Reference publication 1311, NASA," Tech. Rep., NASA, 1996.

[12] C. R. Wilke, "A viscosity equation for gas mixtures," The Journal of Chemical Physics, vol. 18, no. 4, pp. 517-519, 1950.

[13] S. Gordon and B. J. McBride, "Computer program for calculation of complex chemical equilibrium compositions and applications. Part 1: analysis. Reference publication 1311, NASA," Tech. Rep., NASA, 1994.

[14] C. Park, R. L. Jaffe, and H. Partridge, "Chemical-kinetic parameters of hyperbolic earth entry," Journal of Thermophysics and Heat Transfer, vol. 15, no. 1, pp. 76-90, 2001.

[15] A. J. Dean and R. K. Hanson, " $\mathrm{CH}$ and C-atom time histories in dilute hydrocarbon pyrolysis: measurements and kinetics calculations," International Journal of Chemical Kinetics, vol. 24, no. 6, pp. 517-532, 1992.

[16] T. Kruse and P. Roth, "Kinetics of $\mathrm{C}_{2}$ reactions during high-temperature pyrolysis of acetylene," Journal of Physical Chemistry A, vol. 101, no. 11, pp. 2138-2146, 1997.

[17] D. L. Baulch, C. J. Cobos, R. A. Cox et al., "Evaluated kinetic data for combustion modelling," Journal of Physical Chemistry Reference Data, vol. 21, no. 3, pp. 411-429, 1992.

[18] C. Park, J. T. Howe, R. L. Jaffe, and G. V. Candler, "Review of chemical-kinetic problems of future NASA missions, II: Mars entries," Journal of Thermophysics and Heat Transfer, vol. 8, no. 1, pp. 9-23, 1994.

[19] W. Tsang, "Chemical kinetic data base for propellant combustion 2: reactions involving CN, NCO, and HNCO," Journal of Physical Chemistry Reference Data, vol. 21, no. 4, pp. 753-791, 1992.

[20] NIST Chemical Kinetics Database, ver. 7.0, 2003.

[21] W. Tsang and J. T. Herron, "Chemical kinetic data base for propellant combustion 1: reactions involving $\mathrm{NO}, \mathrm{NO}_{2}$, $\mathrm{HNO}, \mathrm{HNO}_{2}, \mathrm{HCN}$ and $\mathrm{N}_{2} \mathrm{O}$," Journal of Physical Chemistry Reference Data, vol. 20, no. 4, pp. 609-663, 1991. 
[22] A. J. Dean, R. K. Hanson, and C. T. Bowman, "High temperature shock tube study of reactions of $\mathrm{CH}$ and $\mathrm{C}$-atoms with $\mathrm{N}_{2}$," in Proceedings of the 23rd Symposium (International) on Combustion, pp. 259-265, 1990.

[23] T. Sommer, T. Kruse, and P. Roth, "Perturbation study on the reaction of $\mathrm{C}_{2}$ with $\mathrm{N}_{2}$ in high-temperature $\mathrm{C}_{60} / \mathrm{Ar}+\mathrm{N}_{2}$ mixtures," Journal of Physical Chemistry A, vol. 101, no. 20, pp. 3720-3725, 1997.

[24] S. T. Wooldridge, R. K. Hanson, and C. T. Bowman, "A shock tube study of reactions of $\mathrm{CN}$ with $\mathrm{HCN}, \mathrm{OH}$, and $\mathrm{H}_{2}$ using $\mathrm{CN}$ and $\mathrm{OH}$ laser absorption," International Journal of Chemical Kinetics, vol. 28, no. 4, pp. 245-258, 1996.

[25] D. F. Davidson and R. K. Hanson, "High temperature reaction rate coefficients derived from $\mathrm{N}$-atom ARAS measurements and excimer photolysis of NO," International Journal of Chemical Kinetics, vol. 22, no. 8, pp. 843-861, 1990.

[26] A. J. Dean, D. F. Davidson, and R. K. Hanson, "A shock tube study of reactions of $\mathrm{C}$ atoms with $\mathrm{H}_{2}$ and $\mathrm{O}_{2}$ using excimer photolysis of $\mathrm{C}_{3} \mathrm{O}_{2}$ and $\mathrm{C}$ atom atomic resonance absorption spectroscopy," The Journal of Physical Chemistry, vol. 95, no. 1, pp. 183-191, 1991.

[27] T. R. Roose, R. K. Hanson, and C. H. Kruger, "Decomposition of $\mathrm{NO}$ in the presence of $\mathrm{NH}_{3}$," in Proceedings of the International Symposium on Shock Tubes and Waves, vol. 11, pp. 245-253, 1978.

[28] C. Park, "Review of chemical-kinetic problems of future NASA missions, I: Earth entries," Journal of Thermophysics and Heat Transfer, vol. 7, no. 3, pp. 385-398, 1993. 

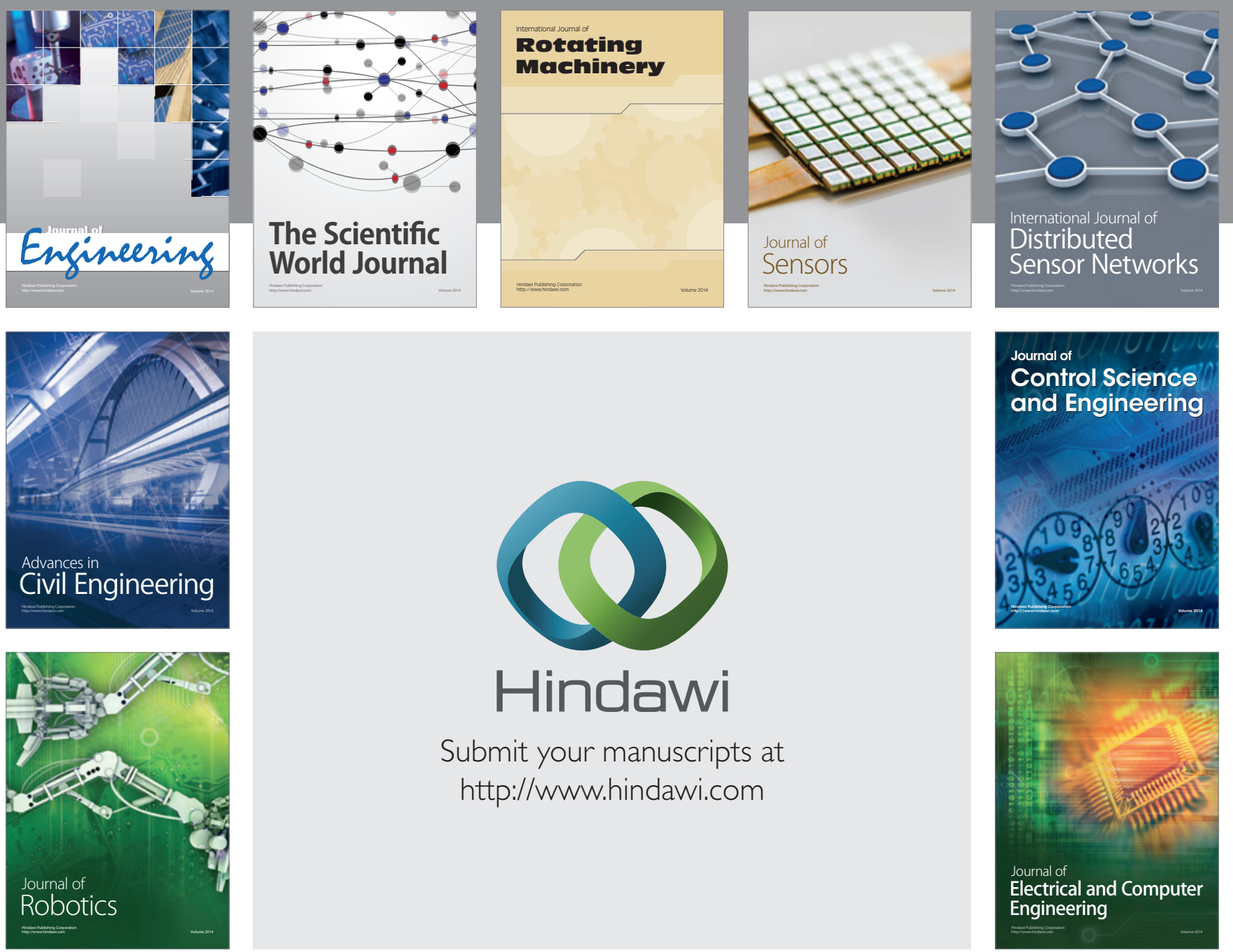

Submit your manuscripts at

http://www.hindawi.com
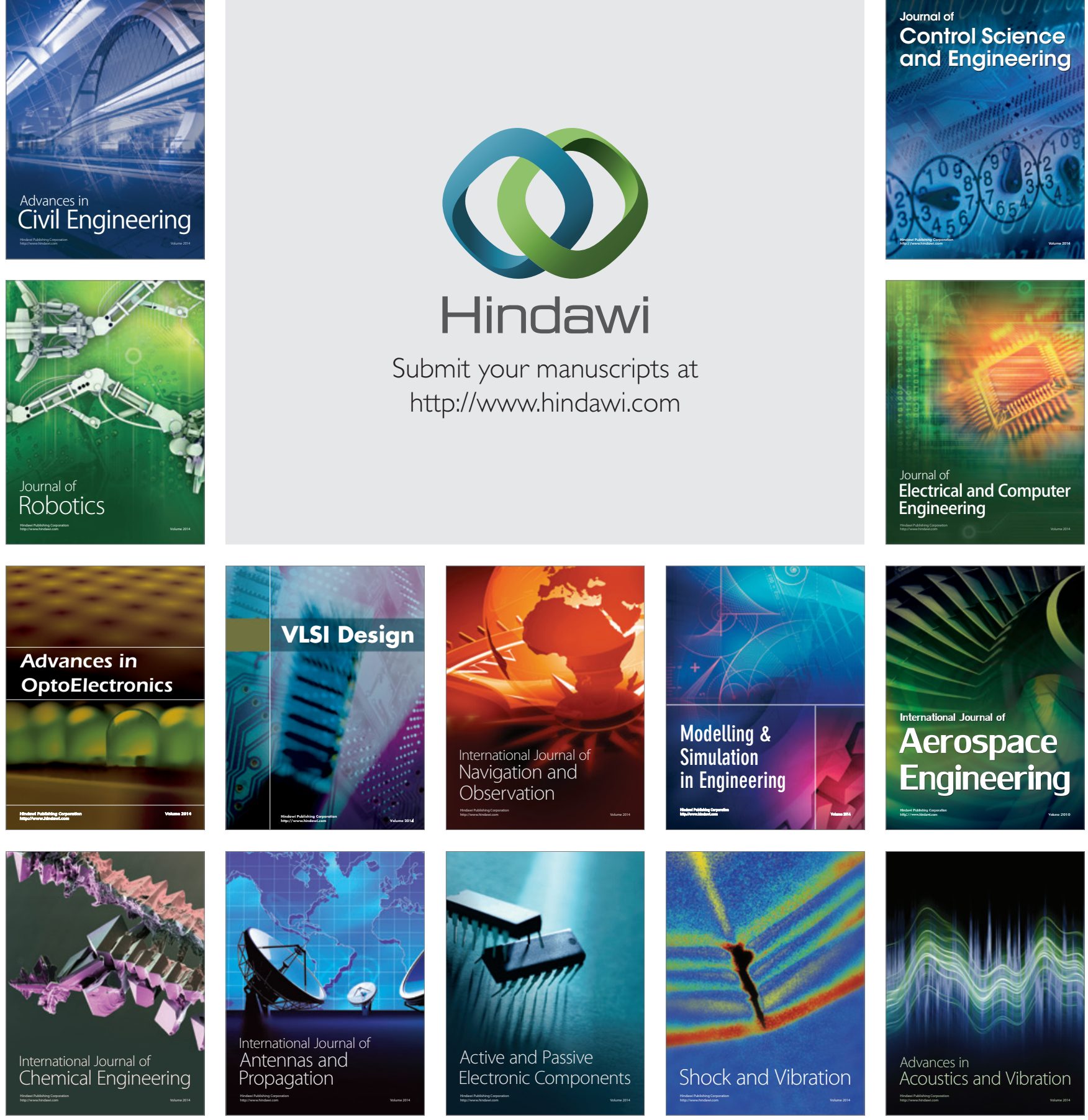